\title{
KINERJA PERAWAT CMHN BERDASARKAN FAKTOR PENGORGANISASIAN PROGRAM CHMN
}

\author{
Sulastri*, Budi Anna Keliat**, Tris Eryando*** \\ Abstrak \\ Penelitian dengan metode kuantitatif dan kualitatif ini bertujuan mengetahui kinerja 55 perawat CMHN, faktor-faktor yang \\ berhubungan dengan kinerja, dan persepsi perawat terhadap hubungan antara pelatihan dengan kinerja perawat CMHN di \\ Pidie, NAD. Hasil analisis bivariat dengan uji chi-square menunjukkan bahwa jenis kelamin $(p=0,047, \alpha=0,05)$, pendidikan \\ $(p=0,001, \alpha=0,05)$, proses rekrutmen ( $p=0,006, \alpha=0,05)$, proses pelatihan ( $p=0,0001, \alpha=0,05)$, supervisi $(p=0,022, \alpha=0,05)$, \\ dan dukungan organisasi $(p=0,006, \alpha=0,05)$ berhubungan dengan kinerja perawat CMHN. Hasil analisis kualitatif dengan \\ teknik content analysis terhadap lima partisipan diketahui bahwa perawat CMHN memperoleh pengetahuan, keterampilan, \\ pengalaman, dan peningkatan produktivitas melalui pelatihan sehingga dapat menampilkan kinerja yang baik sebagai \\ perawat CMHN. Program CMHN disarankan dapat diterapkan baik pada tingkat provinsi maupun kabupaten/ kota untuk \\ meningkatkan kualitas pelayanan kesehatan jiwa masyarakat.
}

Kata kunci: kinerja, perawat CMHN, karakteristik

\begin{abstract}
This quantitative and qualitative research was aimed to identify the performance of 55 CMHN nurses, the influencing factors of their work performance, and nurse's perception toward dominant factors of the performance. The chi-square identified that gender $(p=0,047, \alpha=0,05)$, education $(p=0,001, \alpha=0,05)$, recruitment process $(p=0,006, \alpha=0,05)$, training ( $p=0,0001, \alpha=0,05)$, supervision ( $p=0,022, \alpha=0,05)$, management support factor $(p=0,006, \alpha=0,05)$ were significantly related to the CMHN nurse's work performance. For the approach of qualitative analysis conducted with the technique of content analysis. The qualitative content analysis from the in-depth interview result showed CMHN nurses gained knowledge, skill, experience, and productivity improvement through CMHN training. CMHN program was suggested to be applied at level of province, district/ town to increase the quality of community mental health nursing service.
\end{abstract}

Key words: characteristic, CMHN Nurse, performance

\section{PENDAHULUAN}

Program Community Mental Health Nursing (CMHN) di kabupaten Pidie Aceh yang sudah berjalan selama dua tahun menunjukkan kemajuan yang dicapai, khususnya pada aspek pelayanan pasien gangguan jiwa (Keliat, et al., 2007). Hal ini dilihat dari jumlah pasien yang teridentifikasi 1062 orang. Sebelum dilakukan CMHN, tidak diketahui secara pasti jumlah pasien gangguan jiwa, karena tidak menjadi program. Lima belas orang telah lepas pasung dari 24 pasien yang dipasung di Pidie. Perawat CMHN berjumlah 66 orang yang berasal dari 33 Puskesmas. Penilaian kinerja perawat dilakukan melalui supervisi langsung yaitu melalui penampilan klinik dan supervisi tidak langsung melalui dokumentasi. Penampilan klinik merupakan aspek prestasi kerja dari kinerja perawat CMHN. Aspek lain seperti tanggung jawab, ketaatan, kejujuran, dan kerjasama belum menjadi aspek yang dilihat untuk menilai kinerja perawat.

Program CMHN dibagi dalam tiga tahap yaitu Basic Course (BC)-CMHN, Intermediate Course (IC)-CMHN dan Advanced Course (AC)-CMHN. Kabupaten Pidie baru menerapkan $\mathrm{CMHN}$ pada tingkat dasar (BC-CMHN), berfokus pada asuhan keperawatan pada pasien gangguan jiwa. Selanjutnya akan dilanjutkan pada tingkat IC-CMHN dan ACCMHN. Tahap AC-CMHN akan diberikan psikoterapi oleh perawat spesialis jiwa. Sebelum diterapkan CMHN pada tingkat lebih lanjut, diperlukan penilaian efektifitas program BC-CMHN yang sudah berjalan. Untuk itu, penelitian bertujuan mengidentifikasi faktor-faktor yang berhubungan dengan kinerja perawat dan persepsi perawat terhadap faktor yang paling berhubungan dengan kinerja di kabupaten Pidie Aceh. 


\section{METODE}

Penelitian ini menggunakan metode pendekatan kuantitatif dan kualitatif. Pada pendekatan kuantitatif menggunakan rancangan cross sectional karena semua variabel penelitian dikumpulkan dalam satu waktu (Hick, 1990; Polit \& Hungler, 1999). Analisis kuantitatif dilakukan untuk mengetahui hubungan antara variabel pada penelitian terdiri dari variabel dependen yaitu karakteristik perawat (umur, jenis kelamin, pendidikan) dan pengorganisasian CMHN (rekrutmen, pelatihan, supervisi, dukungan pimpinan, dan pertemuan rutin) dengan variabel dependen kinerja perawat.

Data kuantitatif dikumpulkan dengan pengisian kuesioner. Kuesioner terdiri dari tiga jenis yaitu kuesioner karakteristik responden, pengorganisasian CMHN, dan kuesioner kinerja perawat. Data kualitatif didapat dengan wawancara mendalam. Analisis yang digunakan yaitu analisis kuantitatif dan kualitatif. Analisis kuantitatif menggunakan uji chisquare dan analisis kualitatif dengan content analysis dari Colaizzi (1978, dalam Holloway \& Wheeler, 1996).

Data kualitatif dianalisis dengan tahapan membuat transkrip dan membaca berulang-ulang hasil transkrip wawancara dan catatan lapangan, mengidentifikasi kutipan kata dan pernyataan yang bermakna, membuat kategori-kategori, menentukan tema utama, dan subtema. Metode ini memahami manusia dengan segala kompleksitas sebagai makhluk subyektif, melihat manusia sebagai sistem yang berpola dan berkembang (Poerwandari, 2005).

\section{HASIL}

\section{Hubungan karakteristik perawat dengan kinerja perawat}

Hasil analisis hubungan antara karakteristik perawat $\mathrm{CMHN}$ dengan kinerja menunjukkan bahwa jenis kelamin dan pendidikan menunjukkan hubungan yang bermakna dengan kinerja $(p<0,05)$ (lihat tabel 1).

\section{Hubungan pengorganisasian program $\mathrm{CMHN}$ dengan kinerja perawat $\mathrm{CMHN}$}

Analisis yang dilakukan menunjukkan ada hubungan bermakna antara proses rekrutmen, pelatihan, supervisi, dan dukungan pimpinan dengan kinerja perawat CMHN $(p<0,05)$. Faktor organisasi yang lain yaitu pertemuan rutin tidak menunjukkan hubungan yang bermakna dengan kinerja perawat CMHN $(p>0,05)$ (lihat tabel 2).

Analisis bivariat dari semua variabel independen yang berhubungan dengan kinerja perawat $\mathrm{CMHN}$ mendapatkan hasil jenis kelamin dengan nilai $\mathrm{p}=0,047$ dan $\mathrm{OR}=3,94$, pendidikan dengan nilai $\mathrm{p}=0,001$ dan $\mathrm{OR}=23,3$, proses rekrutmen dengan nilai $\mathrm{p}=0,006$ dan $\mathrm{OR}=7,07$, proses pelatihan dengan nilai $\mathrm{p}=0,0001$ dan $\mathrm{OR}=24.75$, supervisi dengan nilai $\mathrm{p}=0,022$ dan $\mathrm{OR}=4,57$ dan dukungan organisasi dengan nilai $\mathrm{p}=0,006$ dan $\mathrm{OR}=7,07$. Nilai $\mathrm{OR}$ paling tinggi didapat dari variabel proses pelatihan yaitu 24,75 . Ini berarti proses pelatihan memiliki peluang yang lebih besar memperbaiki kinerja perawat dibanding jenis kelamin, pendidikan, rekrutmen, dan supervisi.

Wawancara mendalam dilakukan pada variabel yang paling berhubungan dengan kinerja perawat yaitu pelatihan. Pada umumnya partisipan mengatakan bahwa pelatihan paling berpengaruh terhadap penampilan kerjanya. Hal ini senada dengan informasi dari pimpinan puskesmas dan fasilitator sebagai sumber informasi untuk memvalidasi data.

\section{PEMBAHASAN}

\section{Hubungan karakteristik perawat dengan}

\section{kinerja perawat}

Karakteristik perawat yang berhubungan dengan kinerja perawat adalah jenis kelamin dan pendidikan. Hasil analisis menemukan bahwa perawat perempuan dan yang berpendidikan D III Keperawatan mempunyai peluang untuk menampilkan kinerja yang lebih baik dibandingkan perawat laki-laki dan berpendidikan SPK.

Shye (1991, dalam Ilyas, 2001) mengemukakan bahwa kinerja petugas kesehatan wanita secara total lebih baik dibanding petugas pria, petugas wanita menghabiskan proporsi total kerja mereka dalam pelayanan pasien dan lebih banyak memeriksa pasien. Sebaliknya hasil ini tidak sesuai dengan temuan yang disampaikan oleh Siagian (1999) yang menerangkan bahwa secara sosial budaya, pegawai wanita yang berumah tangga akan memiliki tugas tambahan. 
Hal ini dapat menyebabkan kemangkiran yang lebih sering dibandingkan pegawai pria. Pekerjaan merawat pasien membutuhkan aspek caring yang umumnya ditampilkan oleh perawat perempuan, selain itu pekerjaan keperawatan erat kaitannya dengan perhatian dan empati. Kondisi ini memungkinkan kinerja keperawatan lebih baik dilakukan oleh perawat perempuan.

Siagian (1995) selanjutnya menyatakan makin tinggi tingkat pendidikan seseorang maka makin besar keinginan untuk memanfaatkan pengetahuan dan keterampilan. Gibson, Ivancevich, dan Donnelly (1998) menyatakan bahwa kemampuan dan keterampilan mempengaruhi kinerja. Demikian juga halnya pada perawat dengan pendidikan yang lebih tinggi akan memiliki kemampuan untuk menyerap informasi lebih baik saat pelatihan. Perawat tersebut telah memiliki bekal ilmu pengetahuan sebelum mengikuti pelatihan. Selain itu, tingkat pendidikan yang lebih tinggi juga memungkinkan perawat lebih mudah mengaplikasikan ilmu yang didapat dari pelatihan. Ada hubungan tingkat pendidikan menunjukkan pengalaman mahasiswa D III keperawatan pada praktik keperawatan di komunitas tampaknya menjadi bekal, meskipun materi yang diaplikasikan tidak berfokus pada keperawatan jiwa.

\section{B. Hubungan pengorganisasian program CMHN dengan kinerja perawat $\mathrm{CMHN}$}

Pengorganisasian program CMHN yang berhubungan dengan kinerja perawat $\mathrm{CMHN}$ adalah proses rekrutmen, pelatihan, supervisi dan dukungan organisasi. Berdasarkan analisis, program pelatihan memiliki peluang yang lebih besar untuk memperbaiki kinerja perawat dibandingkan jenis kelamin, pendidikan, rekrutmen, dan supervisi.

Proses rekrutmen dilakukan untuk melihat motivasi perawat terlibat sebagai perawat $\mathrm{CMHN}$. Herzberg (1959 dalam Ilyas, 2001) mengemukakan kinerja seseorang dipengaruhi motivasi, dimana seseorang yang termotivasi akan lebih bertanggung jawab pada pekerjaannya dan berusaha meningkatkan diri. Motivasi timbul dari kebutuhan seseorang yang harus segera dipenuhi untuk segera beraktifitas dan mencapai tujuan. Motivasi dapat diibaratkan sebagai penggerak sedangkan bahan bakarnya adalah kebutuhan (need). Motivasi dalam diri perawat akan kebutuhan catatan yang terstruktur dapat mengoptimalkan pendokumentasian keperawatan. Dengan adanya motivasi akan terjadi pergerakan atau dorongan untuk berperilaku, beraktifitas, untuk mencapai tujuan.

Hal ini sesuai dengan tujuan yang ingin dicapai oleh tim CMHN. Melalui proses rekrutmen yang diawali dengan seleksi dan rekomendasi dari pimpinan puskesmas serta pernyataan tertulis yang menunjukkan komitmen calon perawat $\mathrm{CMHN}$, diharapkan perawat yang aktif dan terlibat sebagai perawat CMHN memiliki motivasi internal yang kuat sehingga dapat melakukan tugasnya dengan baik tanpa paksaaan dari pihak luar

Gunawan (1999) menyatakan bahwa pelatihan berkontribusi sebesar $95 \%$ pada perawat yang mengikuti pelatihan selama masa bakti karena keterampilan mereka bertambah, termasuk keterampilan dalam memberikan asuhan keperawatan pada pasien. Hasil analisis kualitatif diketahui kinerja dipengaruhi oleh pelatihan karena melalui pelatihan perawat CMHN memperoleh pengetahuan dan keterampilan, selain itu pengalaman pun bertambah sehingga meningkatkan produktifitas kerjanya.

Pelatihan merupakan proses pembelajaran yang aplikatif, karena setelah selain memberikan pengetahuan pada aspek kognitif, afektif juga psikomotor. BC-CMHN dilakukan selama 10 hari yang terdiri dari dari teori dan praktik.

Tabel 1

Hasil Analisis Hubungan antara karakteristik perawat CMHN dengan kinerja di Kabupaten Pidie Aceh 2007

\begin{tabular}{|c|c|c|c|c|c|c|}
\hline \multirow{2}{*}{ No } & \multirow{2}{*}{$\begin{array}{l}\text { Karakteristik } \\
\text { Perawat CMHI }\end{array}$} & \multicolumn{2}{|c|}{ Kinerja } & \multirow{2}{*}{ Total } & \multirow[b]{2}{*}{ p } & \multirow{2}{*}{$\begin{array}{c}\text { OR } \\
(95 \% \mathrm{CI})\end{array}$} \\
\hline & & Kurang & Baik & & & \\
\hline \multirow[t]{3}{*}{1.} & Umur & & & & \multirow{3}{*}{0,98} & \multirow{3}{*}{$\begin{array}{c}0,81 \\
(0,242,72)\end{array}$} \\
\hline & $-<30$ tahun & $\begin{array}{c}6 \\
(25 \%)\end{array}$ & $\begin{array}{c}18 \\
(75 \%)\end{array}$ & $\begin{array}{c}24 \\
(100 \%)\end{array}$ & & \\
\hline & - > 30 tahun & $\begin{array}{c}9 \\
(29 \%)\end{array}$ & $\begin{array}{c}22 \\
(71 \%)\end{array}$ & $\begin{array}{c}31 \\
(100 \%)\end{array}$ & & \\
\hline \multirow[t]{3}{*}{2.} & Jenis Kelamin & & & & \multirow{3}{*}{0,047} & \multirow{3}{*}{$\begin{array}{c}3,94 \\
(1,12-13,83)\end{array}$} \\
\hline & - laki-laki & $\begin{array}{c}8 \\
(47,1 \%)\end{array}$ & $\begin{array}{c}9 \\
(52,9 \%)\end{array}$ & $\begin{array}{c}17 \\
(100 \%)\end{array}$ & & \\
\hline & - perempuan & $\begin{array}{c}7 \\
(18,4 \%)\end{array}$ & $\begin{array}{c}31 \\
(81,6 \%)\end{array}$ & $\begin{array}{c}38 \\
(100 \%)\end{array}$ & & \\
\hline \multirow[t]{3}{*}{3.} & Pendidikan & & & & \multirow{3}{*}{0,001} & \multirow{3}{*}{$\begin{array}{c}23,3 \\
(2,78-195,8)\end{array}$} \\
\hline & - SPK & $\begin{array}{c}14 \\
(48,3 \%)\end{array}$ & $\begin{array}{c}15 \\
(51,7 \%)\end{array}$ & $\begin{array}{c}29 \\
(100 \%)\end{array}$ & & \\
\hline & - DIII & $\begin{array}{c}1 \\
(3,8 \%)\end{array}$ & $\begin{array}{c}25 \\
(96,2 \%)\end{array}$ & $\begin{array}{c}26 \\
(100 \%)\end{array}$ & & \\
\hline
\end{tabular}


Pelatihan merupakan pendidikan nonformal. Tujuan pelatihan (training) adalah meningkatkan kemampuan dan keterampilan khusus seseorang atau sekelompok orang. Pelatihan berkaitan dengan peningkatan kemampuan atau keterampilan diberikan pada seseorang yang sebelumnya sudah mempunyai dasar terkait dengan pengetahuan yang akan diberikan pada pelatihan. Dalam suatu pelatihan orientasi atau penekanannya pada tugas tertentu, yaitu: tugas yang harus dilaksanakan, kemampuan psikomotor, dari segi waktu relatif singkat, dan metode belajar yang digunakan lebih inovatif (Notoatmodjo, 2003).

Pelatihan meningkatkan kemampuan bagi seseorang agar semakin menguasai tugasnya. Pelatihan dengan proses pembelajaran yang inovatif dan aplikatif memungkinkan seseorang meningkatkan kemampuan secara psikomotor meskipun diberikan dalam waktu yang relatif singkat.

Proses pelatihan $\mathrm{BC}$ CMHN terdiri pemberian kemampuan kognitif melalui ceramah dan diskusi. Kemampuan psikomotor peserta diberikan melalui simulasi, role play, ujian lab dan supervisi langsung penampilan klinik perawaat saat merawat pasien baik di RSJ dan di Keluarga (komunitas).Perawat CMHN yang ada di kabupaten Pidie memiliki tanggung jawab untuk merawat pasien di wilayahnya. Masing-masing puskesmas memiliki dua perawat CMHN.

Perawatan pasien dilakukan secara berkesinambungan sampai pasien mandiri. Pasien yang sudah mandiri dirawat oleh kader, sementara perawat CMHN merawat pasien lain yang belum mandiri. Survey kepuasan pasien dan keluarga akan pelayanan yang diberikan menunjukkan bahwa keluarga dan pasien merasa puas atas pelayanan perawat CMHN.

Ilyas (2001) menyatakan bahwa supervisi atau kontrol memungkinkan penilaian yang berkesinambungan. Dengan demikian kualitas pekerjaan perawat dapat dijaga dan menjadi optimal.

Penelitian yang dilakukan KMPK-UGM (2006) tentang kinerja bidan desa menunjukkan bahwa tidak adanya supervisi penyelia menjadi salah satu penyebab kinerja rendah. Perawat $\mathrm{CMHN}$ melakukan kunjungan rumah dua kali dalam seminggu dan pada masing-masing kunjungan perawat mengunjungi tiga pasien/keluarga. Dengan adanya supervisi yang dilakukan selama sebulan sekali memungkinkan perawat untuk mendapatkan umpan balik terhadap kinerjanya dan hal ini memungkinkan perawat CMHN terus belajar untuk mengatasi kendala/ hambatan yang ditemui dalam merawat pasien dan keluarga.

Kondisi ini memberikan pola pada perawat untuk senantiasa melakukan tugasnya sesuai dengan standar yang berlaku. Hal ini juga menunjukkan bahwa perawat CMHN sangat loyal terhadap tugasnya. Selain itu fasilitator sebagai supervisor berasal dari lingkungan internal organisasi dan fasilitator nasional melalui pengawasan, memberikan masukan, contoh, dan reward, sehingga hal ini menghasilkan hubungan kerja yang harmonis. aspek mengawasi, memberikan masukan, contoh, dan reward. Gibson, Ivancevich, dan Donely (1995) menyatakan bahwa kualitas pelayanan dapat dipengaruhi oleh pola kepemimpinan yang terdapat dalam organisasi tersebut.

Tabel 2

Hasil Analisis Hubungan antara

Pengorganisasian program CMHN dengan Kinerja di Kabupaten Pidie Aceh 2007

\begin{tabular}{|c|c|c|c|c|c|c|}
\hline \multirow{2}{*}{ No } & \multirow{2}{*}{ Organisasi } & \multicolumn{2}{|c|}{ Kinerja } & \multirow{2}{*}{ Total } & \multirow{2}{*}{$\mathbf{p}$} & \multirow{2}{*}{$\begin{array}{c}\text { OR } \\
(95 \% \mathrm{CI})\end{array}$} \\
\hline & & Kurang & Baik & & & \\
\hline \multirow[t]{5}{*}{1.} & Rekrutmen & & & & & \\
\hline & - Kurang baik & 9 & 7 & 16 & & \\
\hline & & $(56,3 \%)$ & $(43,8 \%)$ & $(100 \%)$ & 0,006 & 7,071 \\
\hline & - Baik & 6 & 33 & 39 & & $(1,896-26,37)$ \\
\hline & & $(15,4 \%)$ & $(84,6 \%)$ & $(100 \%)$ & & \\
\hline \multirow[t]{5}{*}{2.} & Pelatihan & & & & & \\
\hline & - Kurang baik & 11 & 4 & 15 & & \\
\hline & & $(73,3 \%)$ & $(26,7 \%)$ & $(100 \%)$ & 0,0001 & 24,75 \\
\hline & - Baik & 4 & 36 & 40 & & $(5,30-115,64)$ \\
\hline & & $(10 \%)$ & $(90 \%)$ & $(100 \%)$ & & \\
\hline \multirow[t]{5}{*}{3.} & Pertemuan rutin & & & & & \\
\hline & - Kurang baik & 9 & 16 & 25 & & \\
\hline & & $(36 \%)$ & $(64 \%)$ & $(100 \%)$ & 0,3 & 2,25 \\
\hline & - Baik & 6 & 24 & 30 & & $(0,67-7,55)$ \\
\hline & & $(20 \%)$ & $(80 \%)$ & $(100 \%)$ & & \\
\hline \multirow[t]{5}{*}{4.} & Supervisi & & & & & \\
\hline & - Kurang baik & 8 & 8 & 16 & & 4,57 \\
\hline & & $(50 \%)$ & $(50 \%)$ & $(100 \%)$ & 0,022 & $(1,28-16,38)$ \\
\hline & - Baik & 7 & 32 & 39 & & \\
\hline & & $(17,9 \%)$ & $(82,1 \%)$ & $(100 \%)$ & & \\
\hline \multirow[t]{5}{*}{5.} & $\begin{array}{l}\text { Dukungan } \\
\text { pimpinan }\end{array}$ & & & & & \\
\hline & - Kurang baik & 9 & 7 & 16 & & \\
\hline & & $(56,3 \%)$ & $(43,8 \%)$ & $(100 \%)$ & 0,006 & 7,1 \\
\hline & - Baik & 6 & 33 & 39 & & $(1,9-26,4)$ \\
\hline & & $(15,4 \%)$ & $(84,6 \%)$ & $(100 \%)$ & & \\
\hline
\end{tabular}


Kepemimpinan tersebut memiliki unsur yang meliputi sumber kekuasaan; persepsi terhadap jenis kekuasaan; gaya dan pengalaman pemimpin; karakteristik pribadi dan situasi; kebutuhan, pengalaman serta tujuan pengikutnya. Pimpinan sebagai pemelihara standar hasil kerja yang tinggi.

Pimpinan yang memberikan dukungan pada karyawannya dapat merangsang kelompok untuk mengikuti contohnya. Dari pendapat ini dapat disimpulkan bahwa seorang pimpinan yang berada pada ujung tombak dapat memfasilitasi dan mendukung tercapainya penerapan standar asuhan keperawatan jiwa yang baik sesuai dengan tujuan yang diharapkan.

Pelaksanaan CMHN yang dijalankan di kabupaten Pidie sudah sangat dimaklumi oleh pemerintah setempat. Dukungan tidak hanya datang dari pimpinan langsung tetapi sudah menjadi program pemerintah setempat dalam hal ini pemerintah kabupaten untuk menuntaskan atau meminimalkan angka gangguan jiwa di kabupaten Pidie.

Peran serta secara aktif dari pimpinan puskesmas dengan memberikan rekomendasi sejak awal pelatihan, keterlibatan bupati dengan memfasilitasi kegiatan dan anggaran kegiatan melalui dinas kesehatan setempat. Kondisi ini tampaknya merupakan dukungan yang meningkatkan motivasi perawat CMHN untuk senantiasa menampilkan kinerja yang baik terhadap pelaksanaan tugasnya sebagai perawat CMHN di wilayahnya.

\section{KESIMPULAN}

Penelitian initelah mengidentifikasi faktor-faktor yang berhubungan dengan kinerja perawat $\mathrm{CMHN}$ di kabupaten Pidie Aceh pada bulan Juni 2007. Karakteristik perawat yang berhubungan dengan kinerja perawat CMHN yaitu jenis kelamin dan pendidikan dan faktor organisasi yang berhubungan dengan kinerja perawat yaitu proses rekrutmen, pelatihan, supervisi dan dukungan pimpinan. Faktor yang berhubungan dengan kinerja perawat adalah pelatihan.

Saran berdasarkan hasil penelitian ini yaitu Depkes RI diharapkan dapat menetapkan suatu kebijakan yang terkait dengan program pelayanan kesehatan jiwa di Indonesia, Dinas Kesehatan
Propinsi NAD membuat peraturan daerah terkait dengan program pelayanan kesehatan jiwa di NAD, Dinas Kesehatan Kabupaten Pidie membentuk dan menetapkan tim perawat CMHN yang akan melanjutkan program pelayanan CHMN yang telah dikembangkan di Pidie saat ini, serta melakukan evaluasi dan monitoring secara reguler terhadap kinerja perawat CMHN.

Kinerja yang lebih baik tampak pada perawat perempuan dan yang berpendidikan tinggi. Berdasarkan hasil ini disarankan untuk melatih kemampuan empati pada perawat laki-laki, sehingga pasien dan keluarga merasa nyaman meskipun dirawat oleh perawat laki-laki dan meningkatkan pendidikan perawat CMHN secara periodik ke jenjang yang lebih tinggi.

Puskesmas diharapkan dapat menetapkan program pelayanan kesehatan jiwa masyarakat sebagai program utama dalam program pokok pelayanan Puskesmas, perawat $C M H N$ meningkatkan peran dan fungsinya dalam merawat pasien gangguan jiwa sesuai minimal dengan rencana kegiatan yang disusun. Masyarakat dapat memanfaatkan pelayanan $\mathrm{CMHN}$ melalui peran aktif keluarga pasien gangguan jiwa dalam merawat dan mencari bantuan untuk meningkatkan kemandirian pasien yang mengalami gangguan jiwa (A, JS, RU).

\footnotetext{
* Staf Akademik Poltekkes Kemenkes Tanjung Karang, Bandar Lampung

** Staf Akademik Kelompok Keilmuan KeperawatanJiwa FIK UI, Depok

*** Staf Akademik Departemen Biostatistik dan Kependudukan FKM UI, Depok
}

\section{KEPUSTAKAAN}

Departemen Kesehatan RI. (2005). Gangguan kesehatan jiwa. Diperoleh dari http:// www.litbang.depkes.go.id.

Ewen, M. (1998). Community base nursing: an introduction. Philadelphia: W.B. Saunder Company.

Gilbson, Ivancevich, \& Donnelly. (1996). Organisasi (8th Ed). Terjemahan. Jakarta: Bina Rupa Aksara. 
Holloway, I., \& Wheeler, S. (1996). Qualitative research for nurses. USA: Blackwell science Ltd.

Ilyas, Y. (2001). Kineja: Teori, penilaian dan penelitian. Jakarta: Pusat Kajian ekonomi Kesehatan FKMUI.

Keliat, B.A., Daulima, N.H.C., Nurhaeni, H., \& Akemat (Editor). (2006). Modul basic course community mental health nursing. Jakarta: WHO-FIK UI.

Keliat, B.A., et al. (2007). Laporan basic course community mntal helath nursing Kabupaten Pidie NAD 2007. Jakarta: WHO-FIK UI.

KMPK-UGM. (2006). Evaluasi kinerja bidan puskesmas dalam pelayanan antenatal di Kabupaten Puncak Jaya. Diperoleh dari http:/ /www.kmpk.ugm.ac.id/id/index.
Notoatmodjo, S. (2003). Pengantar pendidikan kesehatan dan ilmu perilaku kesehatan, Yogyakarta: Andi Offset.

Poerwandari, E.K. (2005). Pendekatan kualitatif untuk penelitian perilaku manusia (edisi 3). Jakarta: LPSP3 UI.

Siagian, S.P. (1995). Teori motivasi dan Aplikasinya. (edisi pertama). Jakarta: Bina Aksara

Siagian, S.P. (1999). Manajemen sumber daya manusia. Jakarta: Bumi Aksara

Townsend. (2005). Psychiatric mental health nursing. (9th edition). Philadelphia: Lippincott.

Orang yang membuat keberhasilan dalam hidup adalah orang yang siap sedia melihat tujuannya dan melangkah menujunya dengan tak pernah goyah.

Itulah pengabdian.

- Denis Waitley -

Suatu kriteria yang baik untuk mengukur keberhasilan dalam kehidupan Anda ialah jumlah orang yang telah anda buat bahagia.

- Stephen Covey -

Bukan kurangnya pengetahuan yang menghalangi keberhasilan, tetapi tidak cukupnya tindakan.

Dan bukan kurang cerdasnya pemikiran yang melambatkan perubahan hidup ini, tetapi kurangnya penggunaan dari pikiran dan kecerdasan.

- Mario Teguh - 